\title{
Seleksi Generasi Awal untuk Toleransi terhadap Suhu Tinggi pada Padi
}

\section{Early Generation Selection for Tolerance to High-Temperature Stress in Rice}

\author{
Desta Wirnas $^{1 *}$, Usamah Jaisyurahman², Siti Marwiyah ${ }^{1}$, Trikoesoemaningtyas ${ }^{1}$, \\ Heni Purnamawati ${ }^{1}$, dan Surjono Hadi Sutjahjo ${ }^{1}$
}

${ }^{1}$ Departemen Agronomi dan Hortikultura, Fakultas Pertanian, Institut Pertanian Bogor (IPB University), Jl. Meranti, Kampus IPB Darmaga, Bogor 16680, Indonesia ${ }^{2}$ Program Studi Pemuliaan dan Bioteknologi Tanaman, Sekolah Pascasarjana, Institut Pertanian Bogor

Diterima 27 Maret 2020/Disetujui 16 Juni 2020

\begin{abstract}
The impacts of high-temperature stress on rice growth and productivity can be mitigated by growing tolerant varieties. This research was conducted to estimate the genetic parameters and to select the best genotypes based on the susceptibility stress index (SSI). This research was conducted from August 2016 to February 2017. Half of the five weeks seedling tiller of each $F_{3}$ plant was transferred to new pot culture so that each genotype of the $F_{3}$ rice population grown in two pots. At the maximum vegetative phase, the parental and $F_{3}$ populations were treated under two different temperatures: in the open ground area and inside a greenhouse with daily mean temperatures of $38.89 / 22.67{ }^{\circ} \mathrm{C}$ dan $41.62 / 23.32{ }^{\circ} \mathrm{C}$, respectively. The traits observed were yield and yield components. The results showed that the grain yield of the parents and the $F_{3}$ population were lower when grown inside the greenhouse. The filled grain number per panicle was controlled by additive gene action in these two environments, and is suggested to be a selection character. Selection based on SSI index obtained 13 genotypes tolerant to heat stress and had higher yield compared to their parents. SSD method combined with shuttle breeding is recommended as a breeding method to produce tolerant and high yielding lines.
\end{abstract}

Keywords: heat stress, heritability, segregating population, SSI

\section{ABSTRAK}

Dampak suhu tinggi pada pertumbuhan dan produktivitas padi dapat dikurangi dengan menanam varietas toleran. Tujuan penelitian ini adalah memperoleh informasi tentang kendali genetik serta mengidentifikasi genotipe toleran berdasarkan nilai susceptibility stress index (SSI). Penelitian dilakukan dari Agustus 2016 hingga Februari 2017. Saat fase vegetatif maksimum tetua dan populasi $F_{3}$ diperlakukan di bawah dua kondisi suhu, yaitu di lantai jemur dan rumah kaca dengan suhu maksimum dan minimum rata-rata masing-masing $38.89 / 22,67{ }^{\circ} \mathrm{C}$ dan $41.62 / 23.32{ }^{\circ} \mathrm{C}$. Karakter yang diamati adalah hasil dan komponen hasil. Hasil penelitian menunjukkan bahwa kondisi suhu tinggi mempengaruhi pertumbuhan dan hasil pada tetua dan populasi $F_{3}$. Terdapat keragaman karakter agronomi padi pada kondisi cekaman suhu tinggi. Jumlah gabah isi per malai adalah satu-satunya karakter yang dikendalikan oleh aksi gen aditif dengan nilai heritabilitas tergolong tinggi pada cekaman suhu di lantai jemur dan dalam rumah kaca sehingga karakter ini dapat digunakan untuk mengidentifikasi individu toleran pada generasi awal. Terdapat 13 individu yang toleran terhadap cekaman suhu tinggi berdasarkan nilai SSI. Karakter bobot gabah isi dikendalikan oleh gen-gen non aditif sehingga dianjurkan seleksi untuk peningkatan bobot gabah isi dilakukan pada generasi lanjut. Metode SSD direkomendasikan sebagai metode untuk perbaikan toleransi terhadap suhu tinggi dikombinasikan dengan metode shuttle breeeding.

Kata kunci: fertilitas, indeks, perubahan iklim, toleran

\section{PENDAHULUAN}

Padi (Oryza sativa L.) adalah tanaman pangan penting yang pertumbuhan dan produktivitasnya dipengaruhi oleh kenaikan dan penurunan suhu. Suhu adalah faktor yang

\footnotetext{
* Penulis untuk korespondensi. e-mail: dwirnas@gmail.com
}

mempengaruhi pertumbuhan dan perkembangan tanaman (Hatfield dan Prueger, 2015). Peningkatan suhu muka bumi saat ini sebagai akibat pemanasan global (IPCC, 2014) diprediksi akan menjadi faktor pembatas produktivitas tanaman.

Fase pertumbuhan padi yang paling sensitif terhadap suhu tinggi adalah fase berbunga karena menyebabkan kemandulan bunga betina (Tenorio et al., 2013; Cheabu et 
al., 2018) dan reduksi serbuk sari yang menyerbuki stigma (Das et al., 2014). Kondisi suhu tinggi selama periode pengisian dan pemasakan biji juga dapat memengaruhi kualitas beras dengan meningkatnya butir kapur pada beras (Miyahara et al., 2017).

Penggunaan varietas toleran merupakan salah satu alternatif untuk mengatasi kondisi suhu tinggi dalam budidaya padi (Yaliang et al., 2019). Jaisyurahman et al. (2019) melaporkan bahwa genotipe toleran menunjukkan persentase penurunan hasil lebih rendah dibandingkan dengan varietas peka. Varietas toleran memiliki hasil lebih tinggi dan kualitas lebih baik, yaitu persentase butir kapur lebih rendah dibandingkan dengan varietas peka (Tanamachi et al., 2016).

Pemuliaan untuk mengembangkan varietas berdaya hasil baik dan toleran terhadap cekaman suhu tinggi membutuhkan informasi kendali genetik. Hal ini penting dalam pemilihan metode dan karakter seleksi yang efisien serta dapat menduga kemajuan genetik. Kendali genetik terhadap karakter hasil pada padi yang ditanam di bawah kondisi suhu tinggi telah dilaporkan oleh Eswaran dan Anbanandan (2016), namun informasi tentang kendali genetik toleransi terhadap stres suhu tinggi pada generasi awal (populasi bersegregasi) pada tingkat stress yang berbeda belum dilaporkan.

Informasi tentang pola pewarisan karakter hasil dan komponen hasil pada kondisi suhu tinggi sangat diperlukan dalam mendukung pengembangan varietas padi yang toleran terhadap peningkatan suhu. Penggunaan populasi bersegregasi untuk studi genetik pada beberapa tingkat stress juga masih terbatas. Tujuan penelitian ini adalah untuk memperoleh informasi tentang kendali genetik karakter hasil dan komponen hasil pada populasi bersegregasi padi pada dua tingkat stress suhu tinggi serta mengidentifkasi genotipe toleran pada generasi awal.

\section{BAHAN DAN METODE}

Penelitian dilakukan di Kebun Percobaan Cikabayan, Institut Pertanian Bogor, Bogor pada bulan September 2016 sampai Februari 2017. Bahan tanaman yang digunakan adalah 200 individu tanaman $\mathrm{F}_{3}$ hasil persilangan antara dua varietas padi nasional serta kedua tetua, yaitu IPB 6R (tetua peka terhadap suhu tinggi) dan Situ Patenggang (tetua toleran terhadap suhu tinggi) (Wirnas et al., 2015).

Bibit berumur dua minggu dipindahtanamkan ke dalam pot berisi campuran tanah dan pupuk kandang dalam perbandingan 2:1. Tiga minggu kemudian, tanaman dicabut lalu setengah dari jumlah anakan masing-masing tanaman $\mathrm{F}_{3}$ dipindahkan ke pot baru dan setengahnya lagi ditanam kembali pada pot yang sama sehingga terdapat dua set populasi $\mathrm{F}_{3}$ dan ditumbuhkan di lantai jemur sampai tanaman berumur 7 MSS (minggu setelah semai).

Perlakuan cekaman suhu tinggi diberikan sejak masuk fase vegetatif maksimum (7 MSS) sampai panen, yaitu genotipe tetua dan masing-masing set populasi $\mathrm{F}_{3}$ diperlakukan di bawah dua kondisi suhu yang berbeda, yaitu suhu lantai jemur dan suhu di dalam suhu rumah kaca sampai panen. Selama penelitian, rata-rata suhu maksimum/ minimum di lantai jemur adalah $38.89 / 22.67{ }^{\circ} \mathrm{C}$, sedangkan rata-rata suhu maksimum/minimum di dalam rumah kaca adalah 41.62/23.32 ${ }^{\circ} \mathrm{C}$. Pengamatan dilakukan terhadap karakter tinggi tanaman saat panen, periode pengisian biji, panjang malai, jumlah gabah isi per malai, jumlah gabah total per malai, jumlah gabah hampa per malai, bobot 100 butir, dan bobot gabah isi per tanaman. Pemeliharaan tanaman dioptimalkan untuk pemupukan, penyiraman serta pengendalian gulma, hama, dan penyakit.

Analisis data dimulai dengan perhitungan nilai ratarata untuk genotipe tetua (IPB 6R dan Situ Patenggang) dan diukur signifikansinya menggunakan uji-t serta ratarata populasi $\mathrm{F}_{3}$ dengan standar deviasinya. Analisis data dilanjutkan untuk mendapatkan informasi tentang aksi gen, heritabilitas, dan koefisien keragaman genotipe (KKG) berdasarkan Roy (2000).

Tingkat toleransi individu $\mathrm{F}_{3}$ ditentukan berdasarkan nilai indeks sensitifitas terhadap cekaman (SSI $=$ stress susceptibility index). SSI $=\frac{\frac{1-Y p}{Y S}}{S I} ; \mathrm{SI}=\frac{1-X s}{X p}$ (Fischer dan Maurer, 1978), dimana $\mathrm{Yp}=$ hasil pada kondisi tanpa cekaman, Ys = hasil pada kondisi, tercekam suhu tinggi, $\mathrm{Xp}=$ rata-rata hasil seluruh genotipe pada kondisi tanpa cekaman Xs = rata-rata hasil seluruh genotipe pada kondisi tercekam suhu tinggi. Indeks SSI mengitung sifat toleransi berdasarkan penurunan hasil pada kondisi tercekam suhu tinggi, genotipe toleran adalah genotipe dengan nilai SSI $<1$.

\section{HASIL DAN PEMBAHASAN}

\section{Keragaan Tetua dan Populasi $F_{3}$ Padi pada Kondisi Suhu Tinggi}

Hasil penelitian menunjukkan bahwa kedua tetua yang ditumbuhkan di lantai jemur memiliki perbedaan yang signifikan untuk tinggi tanaman, panjang malai, jumlah gabah hampa per malai, dan berat 100 butir. Populasi $\mathrm{F}_{3}$ yang ditumbuhkan di lantai jemur memiliki rata-rata tinggi tanaman lebih tinggi, jumlah gabah isi, dan jumlah gabah total lebih banyak, serta persentase gabah isi dan bobot gabah isi lebih tinggi dibandingkan dengan kedua tetuanya (Tabel 1).

Di antara kedua tetua untuk semua karakter yang diamati, kecuali jumlah gabah isi per malai pada tingkat cekaman suhu di dalam rumah kaca menunjukkan perbedaan yang signifikan. Rata-rata karakter tinggi tanaman, jumlah gabah isi, jumlah gabah total per malai, dan persentase gabah isi lebih tinggi pada populasi $\mathrm{F}_{3}$ dibanding keduanya (Tabel 2).

Peningkatan suhu menyebabkan gangguan pertumbuhan dan hasil pada genotipe tetua dan populasi $\mathrm{F}_{3}$. Penurunan hasil dilaporkan terjadi karena gangguan pada viabilitas polen. Menurut Nishiyama and Satake (1981); Jagadish et al. (2007); dan Jaisyurahman et al. (2019) cekaman suhu tinggi menyebabkan meningkatnya jumlah polen yang steril sehingga jumlah gabah hampa juga meningkat. Penurunan viabilitas polen sebanyak $25 \%$ pada genotipe peka dan $9 \%$ pada genotipe toleran 
Tabel 1. Keragaan genotipe tetua dan populasi $\mathrm{F}_{3}$ yang ditumbuhkan di lantai jemur

\begin{tabular}{|c|c|c|c|c|}
\hline Karakter & $\begin{array}{l}\text { Rata-rata } \\
\text { IPB 6R }\end{array}$ & $\begin{array}{c}\text { Rata-rata } \\
\text { Situ Patenggang }\end{array}$ & $\mathrm{t}$-test & $\begin{array}{c}\text { Rata-rata dan standar } \\
\text { deviasi populasi } \mathrm{F}_{3}\end{array}$ \\
\hline Tinggi tanaman saat panen $(\mathrm{cm})$ & 118.2 & 95.8 & $* *$ & $141.9 \pm 15.1$ \\
\hline Periode pengisian biji (hari) & 27.1 & 36.3 & ns & $34.6 \pm 6.7$ \\
\hline Panjang malai (cm) & 28.4 & 25.7 & $*$ & $28.3 \pm 2.7$ \\
\hline Jumlah gabah isi per malai & 77.2 & 85.9 & ns & $172.4 \pm 66.3$ \\
\hline Jumlah gabah hampa per malai & 118.9 & 63.6 & $* *$ & $60.5 \pm 38.6$ \\
\hline Jumlah gabah total per malai & 196.1 & 149.5 & ns & $232.9 \pm 61.7$ \\
\hline Persentase gabah isi (\%) & 38.3 & 54.9 & ns & $72.8 \pm 16.6$ \\
\hline Bobot 100 butir (g) & 2.0 & 2.4 & $* *$ & $2.4 \pm 0.3$ \\
\hline Bobot gabah isi per tanaman $(\mathrm{g})$ & 24.5 & 26.6 & ns & $32.1 \pm 19.2$ \\
\hline
\end{tabular}

Keterangan: * = berbeda nyata pada $\mathrm{p}<5 \%$;* = berbeda nyata pada $\mathrm{p}<1 \%$; ns $=$ tidak berbeda nyata berdasarkan uji t

dilaporkan pada tanaman tomat ketika diekpos pada kondisi suhu tinggi (Mazzeo et al., 2018). Selain itu, Cheabu et al. (2019) melaporkan bahwa fertilitas polen adalah sifat terkait toleransi terhadap suhu tinggi yang menentukan jumlah butir yang diisi.

Genotipe Situ Patenggang menunjukkan keragaan yang lebih baik dibandingkan IPB 6R pada kedua kondisi lingkungan tumbuh. Hal ini sejalan dengan hasil penelitian sebelumnya (Manalu et al., 2017; Jaisyurahman et al., 2019). Populasi $F_{3}$ memiliki keragaman yang ditunjukkan oleh standar deviasi masing-masing karakter. Terdapat individu-individu yang memiliki keragaan lebih baik dari kedua tetuanya.

Kendali Genetik terhadap Karakter Agronomi Padi pada Kondisi Suhu Tinggi

Kendali genetik terhadap karakter agronomi pada kondisi suhu di lantai jemur terdapat pada Tabel 3. Keragaman karakter agronomi padi populasi $\mathrm{F}_{3}$ dikendalikan oleh aksi gen aditif dan epistasis. Karakter panjang malai, jumlah gabah isi, dan jumlah gabah total. Nilai heritabilitas semua karakter yang diamati berkisar antara 18.05-59.90\% dengan jumlah gabah isi merupakan karakter dengan heritabilitas tertinggi. Di antara karakter yang diamati, jumlah gabah isi, jumlah gabah hampa, dan bobot biji per tanaman merupakan karakter yang memiliki koefisien keragaman genetik tertinggi.

Kilasi et al. (2018) melaporkan adanya keragaman genetik populasi padi hasil persilangan antara N22 × IR64 dengan nilai heritabilitas tergolong tinggi pada kondisi cekaman suhu tinggi, sedangkan Elbashier et al. (2019) melaporkan untuk tanaman gandum.

Dalam kondisi cekaman di rumah kaca, yaitu pada kondisi suhu yang lebih tinggi, sebagian besar karakter yang diamati dikendalikan oleh aksi gen dominan dan epistasis. Hanya karakter tinggi tanaman dan jumlah gabah isi yang dikendalikan oleh banyak gen aditif. Nilai heritabilitas semua karakter yang diamati tergolong sedang atau tinggi, kecuali karakter tinggi tanaman (Tabel 4).

Hasil penelitian ini menunjukkan bahwa tingkat cekaman mempengaruhi kendali genetik terhadap suatu karakter. Terdapat aksi gen yang berbeda pada karakter yang sama (Tabel 3 dan Tabel 4). Dalam kondisi cekaman

Tabel 2. Keragaan genotipe tetua dan populasi $\mathrm{F}_{3}$ padi yang ditumbuhkan di dalam rumah kaca

\begin{tabular}{|c|c|c|c|c|}
\hline Karakter & $\begin{array}{l}\text { Rata-rata } \\
\text { IPB 6R }\end{array}$ & $\begin{array}{c}\text { Rata-rata } \\
\text { Situ Patenggang }\end{array}$ & $\mathrm{t}$-test & $\begin{array}{l}\text { Rata-rata dan standar } \\
\text { deviasi populasi } \mathrm{F}_{3}\end{array}$ \\
\hline Tinggi tanaman saat panen $(\mathrm{cm})$ & 125.9 & 103.3 & $* *$ & $127.8 \pm 17.9$ \\
\hline Periode pengisian biji (hari) & 30.6 & 35.1 & $* *$ & $33.9 \pm 7.0$ \\
\hline Panjang malai (cm) & 27.3 & 24.5 & $*$ & $25.7 \pm 3.6$ \\
\hline Jumlah gabah isi per malai & 57.0 & 54.1 & $\mathrm{~ns}$ & $100.3 \pm 46.1$ \\
\hline Jumlah gabah hampa per malai & 107.8 & 44.3 & $* *$ & $69.6 \pm 34.6$ \\
\hline Jumlah gabah total per malai & 164.8 & 98.3 & $* *$ & $171.7 \pm 49.8$ \\
\hline Persentase gabah isi (\%) & 34.8 & 55.0 & $* *$ & $57.1 \pm 19.6$ \\
\hline Bobot 100 butir (g) & 1.9 & 2.1 & $* *$ & $1.9 \pm 0.4$ \\
\hline Bobot gabah isi per tanaman $(\mathrm{g})$ & 11.4 & 20.6 & $* *$ & $19.1 \pm 10.1$ \\
\hline
\end{tabular}

Keterangan: $*=$ berbeda nyata pada $\mathrm{p}<5 \%$;* $=$ berbeda nyata pada $\mathrm{p}<1 \%$; ns $=$ tidak berbeda nyata berdasarkan uji $\mathrm{t}$ 
Table 3. Kendali genetik terhadap karakter agronomi padi pada kondisi suhu tinggi di lantai jemur

\begin{tabular}{|c|c|c|c|c|}
\hline Karakter & Jumlah gen & Aksi gen & $\begin{array}{c}\text { Heritabilitas arti luas } \\
(\%)\end{array}$ & $\begin{array}{l}\text { Koefisien keragaman } \\
\text { genetik }(\%)\end{array}$ \\
\hline Tinggi tanaman saat panen $(\mathrm{cm})$ & Sedikit & Epistasis duplikat & 47.50 & 8.37 \\
\hline Periode pengisian biji (hari) & Sedikit & Epistasis komplementer & 25.73 & 9.82 \\
\hline Panjang malai (cm) & Banyak & Aditif & 25.32 & 4.77 \\
\hline Jumlah gabah isi per malai & Banyak & Aditif & 59.90 & 29.76 \\
\hline Jumlah gabah hampa per malai & Sedikit & Epistasis komplementer & 27.99 & 33.74 \\
\hline Jumlah gabah total per malai & Banyak & Aditif & 38.86 & 16.53 \\
\hline Bobot 100 butir (g) & Banyak & Epistasis komplementer & 18.05 & 5.97 \\
\hline Bobot gabah isi per tanaman $(\mathrm{g})$ & Sedikit & Epistasis komplementer & 44.56 & 39.99 \\
\hline
\end{tabular}

suhu di lantai jemur dan kondisi suhu rumah kaca sebagian besar karakter yang diamati dikendalikan oleh aksi gen non aditif. Hal ini menunjukkan bahwa keragaman genetik pada populasi $\mathrm{F}_{3}$ padi dalam kondisi cekaman suhu tinggi lebih besar disebabkan oleh aksi gen-gen non aditif. Hal ini sejalan dengan laporan Farooq et al. (2011) pada tanaman gandum dan Jodage et al. (2017) pada tanaman jagung, namun kendali genetik hasil dan toleransi terhadap suhu tinggi pada padi belum banyak dilaporkan.

Seleksi berdasarkan karakter yang dikendalikan oleh gen non aditif sebaiknya dilakukan pada generasi lanjut, sedangkan oleh gen aditif di generasi awal (Roy, 2000). Berdasarkan hasil penelitian ini diketahui bahwa jumlah gabah isi per malai dikendalikan oleh aksi gen aditif dan memiliki heritabilitas tinggi sehingga karakter ini dapat digunakan sebagai karakter seleksi pada generasi awal melalui pengamatan secara visual di lapang. Menurut Roy (2000) dan Perera et al. (2014) seleksi berdasarkan karakter dengan aksi gen aditif akan menghasilkan kemajuan genetik yang tinggi.

\section{Identifikasi Individu Tolerant terhadap Cekaman Suhu} Tinggi pada Populasi $F_{3}$

Dalam penelitian ini juga dapat diidentifikasi individu toleran pada generasi awal. Identifikasi genotipe toleran dapat dilakukan menggunakan indeks toleransi (Stress Tolerance Index $=\mathrm{STI}$ ) atau indeks sensitifitas (Stress Susceptibility Index = SSI) (Fischer dan Maurer, 1978). STI dan SSI menilai genotipe toleran berdasarkan keragaan relatifnya pada dua lingkungan, yaitu lingkungan tanpa cekaman (tingkat cekaman rendah) dan lingkungan bercekaman berat.

Penelitian ini menunjukkan bahwa nilai SSI individuindividu pada populasi $\mathrm{F}_{3}$ yang dibangun dari karakter jumlah gabah isi per malai berkisar antara 0.0 hingga 2.5. Terdapat 13 individu yang toleran pada kondisi tercekam suhu tinggi yang ditandai dengan nilai SSI $<0.5$ (Tabel 5). Tiga belas Individu yang terindentifikasi toleran dikelompokkan ke dalam empat kelompok jika dibandingkan terhadap ratarata individu terpilih pada masing-masing kondisi cekaman. Individu nomor 22, 84, 240 memiliki bobot gabah isi lebih tinggi pada kedua kondisi cekaman suhu tinggi dibandingkan dengan individu terpilih lainnya. Individu nomor 186, 125 , dan 129 menunjukkan bobot gabah isi lebih tinggi pada kondisi cekaman di lantai jemur, sedangkan individu nomor 95, 100, 110, dan 245 menunjukkan bobot gabah isi lebih tinggi pada kondisi cekaman di rumah kaca. Individu yang memiliki bobot gabah lebih rendah pada kedua kondisi cekaman adalah nomor 93, 116, dan 137. Individu nomor $22,84,95,100,110,137,186,240,245$ terbukti sebagai individu toleran dan memiliki bobot gabah isi lebih tinggi

Table 4. Kendali genetik terhadap karakter agronomi padi pada kondisi suhu tinggi di rumah kaca

\begin{tabular}{|c|c|c|c|c|}
\hline Karakter & Jumlah gen & Aksi gen & $\begin{array}{l}\text { Heritabilitas arti luas } \\
\qquad(\%)\end{array}$ & $\begin{array}{c}\text { Koefisien keragaman } \\
\text { genetik }(\%)\end{array}$ \\
\hline Tinggi tanaman saat panen $(\mathrm{cm})$ & Banyak & Aditif & 19.09 & 6.17 \\
\hline Periode pengisian biji (hari) & Banyak & Aditif & 83.76 & 18.79 \\
\hline Panjang malai $(\mathrm{cm})$ & Sedikit & Epistasis duplikat & 49.95 & 9.99 \\
\hline Jumlah gabah isi per malai & Banyak & Aditif & 81.41 & 41.49 \\
\hline Jumlah gabah hampa per malai & Banyak & Dominan & 66.26 & 40.50 \\
\hline Jumlah gabah total per malai & Banyak & Dominan & 74.25 & 25.00 \\
\hline Persentase gabah isi (\%) & Banyak & Dominan & 57.43 & 25.97 \\
\hline Bobot 100 butir (g) & Sedikit & Epistasis duplikat & 61.44 & 15.99 \\
\hline Bobot gabah isi per tanaman $(\mathrm{g})$ & Banyak & Dominan & 63.82 & 42.50 \\
\hline
\end{tabular}


dibandingkan dengan tetuanya pada kedua kondisi cekaman suhu tinggi. Genotipe ini diprediksikan sebagai segregant transgresif yang menjadi target dalam pemuliaan untuk tanaman yang diserbuki sendiri.

Seleksi berdasarkan SSI menyebabkan peningkatan rata-rata jumlah gabah isi populasi $\mathrm{F}_{3}$ pada kondisi tingkat cekaman di lantai jemur dan di dalam rumah kaca. Seleksi berdasarkan SSI juga memiliki dampak positif pada nilai bobot gabah per tanaman. Peningkatan nilai tengah bobot gabah isi pada kedua lingkungan sejalan peningkatan rata-rata jumlah gabah isi per malai (Tabel 5). Nilai SSI berkorelasi negatif dengan koefisien korelasi $(\mathrm{r})=-0.28$ dengan bobot gabah isi pada kondisi stress di rumah kaca dan berkorelasi negatif $(r=-0.01)$ dengan penurunan bobot gabah isi akibat cekaman.

Seleksi berdasarkan indeks toleransi dan sensitivitas berhasil mengidentifikasi genotipe toleran dan meningkatkan hasil pada kondisi cekaman. SSI telah diterapkan untuk memilih genotipe yang toleran terhadap cekaman abiotik dan telah menunjukkan perbaikan karakter hasil di beberapa tanaman (Khan dan Durve, 2016; Jamshidi dan Javanmard, 2018). Seleksi genotipe toleran terhadap suhu tinggi berdasarkan indeks toleransi (STI) yang dibangun dari karakter kehijauan daun dilaporkan oleh Qiang et al. (2018).
Nilai indeks toleransi terhadap suhu tinggi berkorelasi positif dengan hasil pada tercekam dan berkorelasi negatif dengan penurunan akibat cekamam. Elbashier et al. (2019) melaporkan bahwa STI dan SSI dapat menentukan tingkat toleransi 250 genotipe gandum terhadap cekaman suhu tinggi.

Tujuan utama pemuliaan tanaman pangan menyerbuk sendiri adalah perbaikan potensi hasil selain perbaikan toleransi sehingga fiksasi gen-gen yang mengendalikan hasil dan toleransi perlu dilakukan bersama-sama. Berdasarkan kendali genetik yang diperoleh dari hasil penelitian ini, maka metode single seed descent dapat disarankan sebagai metode pemuliaan untuk perbaikan hasil dan toleransi terhadap cekaman yang dikombinasikan metode shuttle breeeding. Melalui metode SSD memungkinkan memfiksasi gen-gen aditif tanpa dilakukan seleksi sehingga dapat menghasilkan galur murni yang sama baiknya dengan metode pedigree (Snape dan Riggs 1975; Collard, et al., 2017). Salah satu penerapan metode shuttle breeding adalah pada generasi $\mathrm{F}_{2}, \mathrm{~F}_{5}$, dan $\mathrm{F}_{6}$ diuji pada lingkungan optimum, sedangkan $\mathrm{F}_{3}$ dan $\mathrm{F}_{4}$ diuji pada lingkungan bercekaman (Acquaah, 2007) sehingga gen-gen yang mengendalikan toleransi dan potensi hasil akan terfiksasi bersama-sama.

Tabel 5. Keragan individu toleran pada populasi $\mathrm{F}_{3}$ berdasarkan nilai SSI (stress susceptibility index)

\begin{tabular}{lccccc}
\hline $\begin{array}{l}\text { Nomor } \\
\text { individu yang } \\
\text { teridentifikasi }\end{array}$ & Nilai SSI & $\begin{array}{c}\text { Jumlah gabah isi per malai } \\
\text { Kondisi cekaman } \\
\text { di lantai jemur }\end{array}$ & $\begin{array}{c}\text { Kondisi cekaman } \\
\text { di rumah kaca }\end{array}$ & $\begin{array}{c}\text { Kondisi cekaman } \\
\text { di lantai jemur }\end{array}$ & $\begin{array}{c}\text { Kondisi cekaman } \\
\text { di rumah kaca }\end{array}$ \\
\hline 186 & 0.000 & 145.2 & 145.2 & 87.99 & 25.07 \\
22 & 0.005 & 172.8 & 172.4 & 57.43 & 30.36 \\
110 & 0.137 & 107.4 & 101.2 & 14.49 & 31.71 \\
245 & 0.141 & 135.6 & 127.6 & 28.71 & 43.43 \\
93 & 0.187 & 155.6 & 143.4 & 16.58 & 24.74 \\
125 & 0.320 & 107.4 & 93.0 & 56.58 & 8.15 \\
95 & 0.367 & 176.8 & 149.6 & 18.06 & 27.92 \\
84 & 0.396 & 207.6 & 173.2 & 48.82 & 28.91 \\
100 & 0.431 & 194.0 & 159.0 & 28.59 & 38.70 \\
240 & 0.440 & 135.6 & 127.6 & 63.75 & 30.21 \\
116 & 0.461 & 112.8 & 91.0 & 39.62 & 21.92 \\
129 & 0.495 & 105.2 & 83.4 & 80.32 & 9.94 \\
137 & 0.498 & 142.0 & 112.4 & 14.28 & 26.62 \\
\hline Rata-rata individu teridentifikasi & 146.0 & 129.2 & 42.70 & 26.70 \\
\hline Rata-rata populasi F $_{3}$ & & 172.4 & 100.3 & 32.10 & 19.10 \\
\hline
\end{tabular}

\section{KESIMPULAN}

Hasil penelitian menunjukkan bahwa kondisi suhu tinggi mempengaruhi pertumbuhan dan hasil pada tetua dan populasi $\mathrm{F}_{3}$. Terdapat keragaman karakter agronomi padi pada kondisi cekaman suhu tinggi. Karakter jumlah gabah isi per malai adalah satu-satunya karakter yang dikendalikan oleh aksi gen aditif dengan nilai heritabilitas tergolong tinggi pada cekaman suhu di lantai jemur dan dalam rumah kaca. Karakter jumlah gabah isi per malai dapat digunakan untuk mengidentifikasi individu toleran pada generasi awal. Terdapat 13 individu yang toleran terhadap cekaman suhu 
tinggi berdasarkan nilai indeks sensitivitas terhadap suhu tinggi. Metode single seed descent dapat dipilih sebagai pemuliaan untuk perbaikan toleransi terhadap cekaman dan hasil yang dikombinasikan metode pemuliaan shuttle breeeding.

\section{UCAPAN TERIMA KASIH}

Terima kasih disampaikan kepada DIKTI yang telah membiayai penelitian ini melalui hibah Desentralisasi IPB Tahun 2014 dengan Kontrak nomor: 083/SP2H/PL/Dit. Litabmas/II/2015 atas nama Desta Wirnas.

\section{DAFTAR PUSTAKA}

Acquaah, G. 2007. Principles of Plant Genetics and Breeding. Blackwell Publishing. Malden, USA.

Cheabu, S., P. Moung-Ngam, S. Arikit, A. Vanavichit, C. Malumpong. 2018. Effects of heat stress at vegetative and reproductive stages on spikelet fertility. Rice Sci. 25:218-226.

Cheabu, S., N. Panichawong, P. Rattanametta, B. Wasuri, P. Kasemsap, S. Arikit, A. Vanavichit, C. Malumpong. 2019. Screening for spikelet fertility and validation of heat tolerance in a large rice mutant population. Rice Sci. 26:229-238.

Collard, B.C.Y., J.C. Beredo, B. Lenaerts, R. Mendoza, R. Santelices, V. Lopena, H. Verdeprado, C. Raghavan, G.B. Gregorio, L. Vial, M. Demont, P.S. Biswas, K.M. Iftekharuddaula, M.A. Rahman, J.N. Cobb, M.R. Islam. 2017. Revisiting rice breeding methodsevaluating the use of rapid generation advance (RGA) for routine rice breeding. Plant Prod. Sci. 20:337-352.

Das, S., P. Krishnan, M. Nayak, B. Ramakrishnan. 2014. High temperature stress effects on pollens of rice (Oryza sativa L.) genotypes. Environ. Exper. Bot. 111:36-46.

Eswaran, R., V. Anbanandan. 2016. Assessment of Genetic Variability, Heritability and Genetic Advance for Heat Tolerance in Rice (Oryza sativa L.). Bull. Env. Pharmacol. Life Sci. [Spl. Issue 2]:157-160.

Elbashier, E.M., E.M.E. Elbashier, S.E. Idris, W. Tadesse, I.S.A. Tahir, A.E.S. Ibrahim, A.M.A. Elhashimi, S.I. Saad, A.A. Idris, H.M. Mustfa. 2019. Genetic variations, heritability, heat tolerance indices and correlations studies for traits of bread wheat genotypes under high temperature. Int. J. Clim. Chang. Str. 11:672-686.
Farooq, J., I. Khaliq, M.A. Ali, M. Kashif, A. Rehman, M. Naveed, Q. Ali, W. Nazeer, A. Farooq. 2011. Inheritance pattern of yield attributes in spring wheat at grain filling stage under different temperature regimes. Aust. J. Crop Sci. 5:1745-1753.

Fischer, R.A., R. Maurer. 1978. Drought resistance in spring wheat (Triticum aestivum L.) cultivars, I. grain yield response. Aust. J. Agri. Res. 29:897-912.

Hatfield, J.L., J.H. Prueger. 2015. Temperature extremes: effect on plant growth and development. Weather and Climate Extremes 10:4-10.

[IPCC] Intergovernmental Panel on Climate Change. 2014: Climate Change 2014: Synthesis Report. Contribution of Working Groups I, II and III to the Fifth Assessment Report of the Intergovernmental Panel on Climate Change. IPCC. Geneva, SWI.

Jagadish, S.V.K., P.Q. Craufurd, T.R. Wheeler. 2007. High temperature stress and spikelet fertility in rice. J. Exp. Bot. 58:1627-1635.

Jaisyurahman, U., D. Wirnas, Trikoesoemaningtyas, H. Purnamawati. 2019. Dampak suhu tinggi terhadap pertumbuhan dan hasil tanaman padi. J. Agron. Indonesia 47:248-254.

Jamshidi, A., H.R. Javanmard. 2018. Evaluation of barley (Hordeum vulgare L.) genotypes for salinity tolerance under field conditions using the stress indices. Ain Shams Enginer. J. 9:2093-2099.

Jodage, K., P.H. Kuchanur, P.H. Zaidi, A. Patil, K. Seetharam, M.T. Vinayan, B. Arunkumar. 2017. Genetic analysis of heat stress tolerance and association of traits in tropical maize (Zea mays L.). Environ. Ecol. 35:23542360 .

Khan, I.M., O.P. Dhurve. 2016. Drought response indices for identification of drought tolerant genotypes in rainfed upland rice (Oryza sativa L.). Int. J. Environ. Sci. Technol. 5:73-83.

Kilasi, N.L., J. Singh, C.E. Vallejos, C. Ye, S.V.K. Jagadish, P. Kusolwa, B. Rathinasabapathi. 2018. Heat stress tolerance in rice (Oryza sativa L.): identification of quantitative trait loci and candidate genes for seedling growth under heat stress. Frontiers Plant Sci. 9:1578. Doi: 10.3389/fpls.2018.01578.

Manalu, V.M.P., D. Wirnas, Sudarsono. 2017. Karakter seleksi pada generasi awal untuk adaptasi padi terhadap cekaman suhu tinggi. J. Agron. Indonesia 45:109-116. 
Mazzeo, M.F., G. Cacace, P. Iovieno P, I. Massarelli, S. Grillo, R.A. Siciliano. 2018. Response mechanisms induced by exposure to high temperature in anthers from thermo-tolerant and thermo-sensitive tomato plants: A proteomic perspective. PLoS ONE 13(7): e0201027. Doi: 10.1371/journal.pone.0201027.

Miyahara, K., T. Wada, J. Sonoda, T. Tsukaguchi, M. Miyazaki, M. Tsubone, O. Yamaguchi, M. Ishibashi, N. Iwasawa, T. Umemoto, M. Kondo. 2017. Detection and validation of QTLs for milky-white grains caused by high temperature during the ripening period in Japonica rice. Breeding Sci. 67:333-339.

Nishiyama, I., T. Satake. 1981. High temperatures damage to rice plants. J. Trop. Agric. 25:14-19.

Perera, U., D. Ratnasekera, S. Senanayake, D.S.Z. Abeysiriwardena. 2014. Genetic parameters and correlations of yield attributing characteristics of weedy rice in Sri Lanka. J. Nat. Sci. Foundation Sri Lanka 42:299-306.

Qiang, L., W. Zheng-rui, L. Ding, W. Jian-wei, Q. Wenchen, M. Xiang-hai, S. Shu-luan, L. Hui-min, Z. Ming-hui, C. Xiu-min, Z. Feng-wu. 2018. Evaluation of a new method for quantification of heat tolerance in different wheat cultivars. J. Integrative Agric. 17:786-795.

Roy, D. 2000. Plant Breeding: Analysis and exploitation of variation. Narosa Publ. House. New Delhi, IN.

Snape, J.W., T.J. Riggs. 1975. Genetical consequences of single seed descent in the breeding of self-pollinating crops. Heredity 35:211-219.

Tanamachi, K., M. Miyazaki, K. Matsuo, C. Suriyasak, A. Tamada, K. Matsuyama, M. Iwaya-Inoue, Y. Ishibashi. 2016. Differential responses to high temperature during maturation in heat-stress tolerant cultivars of Japonica rice. Plant Prod. Sci. 19:300308.

Tenorio, F.A., C. Ye, E. Redoña, S. Sierra, M. Laza, M.A. Argayoso. 2013. Screening rice genetic resources for heat tolerance. SABRAO J. Breeding Genetics 45:371-381.

Yaliang, W., W. Lei, Z. Jianxia, H. Shengbo, C. Huizhe, X. Jing, Z. Yikai, Z. Yongjun, S. Qinghua, Z. Defeng, Z. Yuping. 2019. Research progress on heat stress of rice at flowering stage. Rice Sci. 26:1-10. 